\title{
Composition and Anti-Cyanobacterial Activity of Essential Oils from Six Different Submerged Macrophytes
}

\author{
Hongqiang Wang ${ }^{1,2 *}$, Feng Liang ${ }^{1}$, Lieyu Zhang ${ }^{3 * *}$ \\ 'School of Municipal and Environmental Engineering, Henan University of Urban Construction, \\ Pingdingshan, Henan province 467036, PR China \\ ${ }^{2}$ State Key Laboratory of Freshwater Ecology and Biotechnology, Institute of Hydrobiology, \\ Chinese Academy of Sciences, Wuhan, Hubei Province 430072, PR China \\ ${ }^{3}$ Chinese Research Academy of Environmental Sciences, Beijing 100012, PR China
}

Received: 13.May 2014

Accepted: 8 July 2014

\begin{abstract}
Eutrophication of water due to pollution is one of the most serious environmental problems. The occurrence of toxic cyanobacterial blooms in eutrophic lakes, reservoirs, and recreational waters has become a worldwide problem. The inhibitory allelopathy of plants on harmful algae, which has drawn extensive attention recently, is low-cost and ecologically safe, and some good results have been reported. In this study, volatile organic compounds as major allelochemicals have been isolated from some aquatic plants and identified. The chemical compositions of essential oil isolated from Potamogeton cristatus, Potamogeton maackianus, Potamogeton lucens, Vallisneria spinulosa, Ceratophyllum demersum, and Hydrilla verticillata were analyzed by GC/MS. Thirty components were identified in the oils, mainly including fatty acids, ester, sterol, and ketone, etc. Inhibitory effects of essential oils on Microcystis aeruginosa were also investigated. The inhibition ratio of essential oils on M. aeruginosa was 30.2-41.7\% when the treatment concentration of extracts was at a level of $50.0 \mathrm{mg} / \mathrm{L}$. Hence, the essential oils isolated exhibited a significant anti-cyanobacterial activity.
\end{abstract}

Keywords: anti-cyanobacterial activity, essential oil, Microcystis aeruginosa, GC/MS, submerged macrophytes

\section{Introduction}

Allelochemicals from macrophytes or other organisms that inhibit microalgal growth have gained great interest due to their environmental potential as algaecides in controlling water blooms or red tide [1]. In aquatic ecosystems, varieties of submerged macrophytes were found to effectively inhibit the growth of blue-green algae [2]. For example, Myriophyllum spicatum [3-5], Vallisneria spiralis [2],

*e-mail: wanghq77@hncj.edu.cn

**e-mail: zhanglieyu@163.com (Corresponding author)
Potamogeton crispus [6], Ceratophyllum demersum, and Najas marina [7] showed allelopathic effects on nuisance algae. Xian et al. [2] found that six allelochemicals (2ethyl-3-methylmaleimide, dihydroactinidiolide, 4-oxo- $\beta$ ionone, 3-hydroxy-5, 6-epoxy- $\beta$-ionone, loliolide, and 6hydroxy-3-oxo- $\alpha$-ionone) and an unknown compound from $V$. spiralis had strong inhibitory effects on Microcystis aeruginosa Kütz. M. spicatum could release ellagic acid, gallic acid, pyrogallic acid, (+)-catechin, hydrolyzable tannin (eugeniin) and $\beta-1,2,3$-tri-O-galloyl-4,6-(S)-hexahydroxydiphenoyl-D-glucose (tellimagrandin II) into the culture solution, which inhibits the growth of $M$. aeruginosa 
$[3,8,9]$. Tellimagrandin II is an effective inhibitor of microalgal exoenzymes, and tellimagrandin II has at least two modes of action: inhibition of exoenzymes and inhibition of PSII [9]. Gao et al. [10] researched the algae inhibition activity of phenolic compounds exuded by culture solutions of two submerged freshwater macrophytes ( $V$. spiralis and Hydrilla verticillata) incubated at $10 \mathrm{~g}$ of fresh weight for three days. Results indicated that two plants could release some phenolic allelochemicals into culture solutions to inhibit the growth of $M$. aeruginosa. Gross et al. [7] showed that for Najas, 50\% methanol and for Ceratophyllum 50\% acetone yielded the strongest inhibition in the agar-diffusion assay with various filamentous or chroococcal cyanobacteria as target species. Further fractionation by liquid-liquid extraction (LLE) and solid phase extraction (SPE) procedures showed that both aquatic plants appeared to have more than one active fraction, one being hydrophilic and one moderately lipophilic. The water-soluble allelochemicals may inhibit phytoplankton growth, whereas the lipophilic allelochemicals may act through direct cell-cell contact, e.g., against epiphytes. These results clearly indicate that some macrophytes can be used to control nuisance cyanobacterial growth.

In this study we described the results of GC/MS analyses of essential oils from Potamogeton cristatus, Potamogeton maackianus, Potamogeton lucens, Vallisneria spinulosa, Ceratophyllum demersum, Hydrilla verticillata, and their anti-cyanobacterial activities.

\section{Materials and Methods}

\section{Chemicals}

Anhydrous sodium sulfate (AR), alcohol (AR), diethyl ether (AR), and dimethyl sulfoxide (DMSO, AR) were purchased from Chemical Reagent Company, Shanghai, China. Methanol (HPLC) was purchased from Tedia Company, Inc., USA.

\section{Macrophytes and Extraction of Chemicals}

P. cristatus, P. maackianus, P. lucens, V. spinulosa, $C$. demersum, and $H$. verticillata were collected from Wuhan Botanical Garden, Chinese Academy of Sciences. Plant materials were washed free of debris with regular water and later by deionized water, they were then dried and powdered. An appropriate amount of the powdered sample was soaked in alcohol for 72 hours at room temperature, then filtered with $\mathrm{GF} / \mathrm{C}$ glass fiber filters ( $47 \mathrm{~mm}, 1.2 \mu \mathrm{m}$, purchased from Whatman Maidstone, UK). Pressure was reduced using a vacuum pump, and the filtrates subsequently collected. The alcohol filtrates were evaporated to be close to dryness by rotary evaporator at $39^{\circ} \mathrm{C}$, then an appropriate amount of ultrapure water was added to the alcohol filtrates, and finally fractionated with diethyl ether three times. The diethyl ether filtrates were first dehydrated with sodium sulfate anhydrate and then evaporated to dryness by the rotary evaporator at $39^{\circ} \mathrm{C}$. The diethyl ether extracts were stored at $4^{\circ} \mathrm{C}$ until they were used for GC-MS analysis and biological assay. Fig. 1 shows all the steps used in the study.

\section{Bioassay}

Axenic $M$. aeruginosa obtained from the Culture Collection of Algae at the Institute of Hydrobiology, Chinese Academy of Sciences, was used for cyanobacterial assays. The algae were cultured in sterilized BG11 medium (pH 7.4) under a light intensity of 2500 lux at $25^{\circ} \mathrm{C}$, on a 12:12 hour light:dark cycle. The algae were cultured for four days to reach the exponential phase with the density of $10^{5}-10^{6}$ cells $/ \mathrm{mL}$, and were used for the assay of growth inhibition. The growth medium of all cultures was BG11 [11].

The concentration-response relationships between the allelochemicals and the tested organisms were studied in 50 $\mathrm{mL}$ flasks containing $20 \mathrm{~mL}$ test solution, to which $10^{6}$ cells $\cdot \mathrm{mL}^{-1}$ of $M$. aeruginosa were inoculated. The tested

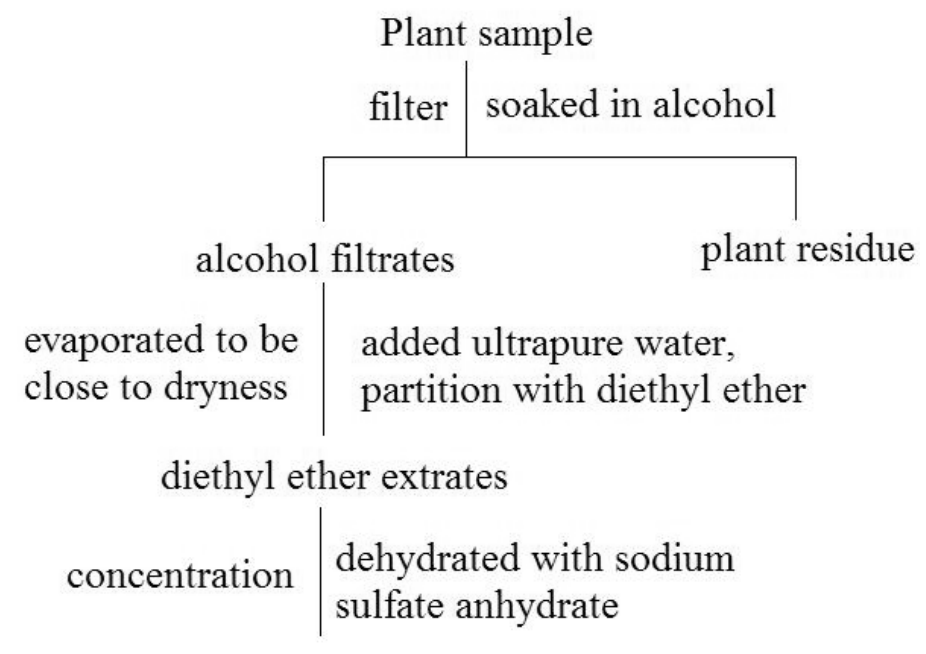

GC-MS analyses

Fig. 1. Flow diagram for the extraction of essential oils from Potamogeton cristatus, Potamogeton maackianus, Potamogeton lucens, Vallisneria spinulosa, Ceratophyllum demersum, and Hydrilla verticillata. 
organisms were exposed, in triplicate, to one concentration level and a control, respectively. The final concentrations of compounds in the test solution were $50 \mathrm{mgL}^{-1}$ for essential oils from $P$. cristatus, $P$. maackianus, $P$. lucens, $V$. spinulosa, $C$. demersum, and $H$. verticillata. The $50 \%$ inhibition concentrations of all essential oils based on cell density of the tested organisms $\left(\mathrm{EC}_{50}\right)$ were determined after exposure for 72 hours. The stock solutions of essential oils were prepared with DMSO, which in the test solution was lower than $0.2 \%(\mathrm{v} / \mathrm{v})$. The test results indicated that the concentrations of DMSO added had no effect on the growth of the tested organisms.

\section{Identification of Essential Oils}

The dried essential oils were analyzed by gas chromatograph-mass spectrometry (GC-MS) (Agilent computerized system consisting of a 6890 gas chromatograph coupled with an Agilent $5973 \mathrm{~N}$ quadrupole mass spectrometer) using an HP-5MS capillary column $(30 \mathrm{~m} \times 0.25 \mathrm{~mm} \times 0.25$ $\mathrm{mm}$ ID). The oven temperature was set at $60^{\circ} \mathrm{C}$ (initial temperature was maintained for $1 \mathrm{~min}$ ) and reached $260^{\circ} \mathrm{C}$ at a rate of $4^{\circ} \mathrm{C} / \mathrm{min}$, and kept constant for $20 \mathrm{~min}$. Helium was used as carrier gas with a flow rate of $1 \mathrm{~mL} / \mathrm{min}$. Mass spectral patterns of the peaks were identified by comparing them with patterns stored in the US National Institute of Standards and Technology (NIST) mass spectral library ver. 2.0 .

\section{Results}

Characterization of volatile components from P. cristatus, P. maackianus, P. lucens, V. spinulosa, C. demersum, and $H$. verticillata were analyzed and identified by gas chromatograph-mass spectrometry (GC-MS). From Table 1 it was found that more than 30 compounds were detected in the essential oils of six submerged macrophytes (Table 1). The composition of the volatile components were different in the six plants. Major volatile components identified from the six macrophytes were fatty acids, ester, ketone, sterol, alkane, amide, naphthalene, and phenanthrene. There were differences in amounts and components of essential oils, which might be due to the differences of plant species. Xian et al. [12] also reported the composition of the volatile substance from $C$. demersum, compared to the results of our studies. There were differences in amounts and components of volatile oils from $C$. demersum, which might be due to the different extraction methods.

Table 2 showed the anti-cyanobacterial activities of essential oils from $P$. cristatus, $P$. maackianus, $P$. lucens, $V$. spinulosa, $C$. demersum, and $H$. verticillata on $M$. aeruginosa. These results indicated that the essential oils isolated from the six submerged macrophytes inhibited the growth of $M$. aeruginosa with inhibition rates being $35.1,36.2,32.9,41.7,30.2$, and 36.6\%, respectively, when the treatment concentration of extracts was at a level of $50.0 \mathrm{mg} / \mathrm{L}$.

\section{Discussion}

Harmful cyanobacterial blooms have increased globally in frequency and intensity and research on their controlling topic are developing simultaneously [13]. Recently, much effort has been paid to allelochemicals, which are potentially important sources of selective and biodegradable algicides [14]. Some allelochemicals have been isolated and their algicidal activities have been demonstrated, such as alkaloids (gramine, berberine) from Arundo donax L. and Coptis chinensis [15, 16], phenolic acids, hydroxy fatty acids, fatty acids from Potamogeton malaianus, Potamogeton maackianus, Typha latifolia, and Arundo donax $[17,18]$.

Submerged macrophytes can stabilize clear-water states in shallow eutrophic lakes by releasing allelopathic compounds that reduce epiphyton and phytoplankton biomass [19]. Zhang et al. [20] isolated and identified 3 allelochemicals (linoleic acid, tetradecanoic, and hexadecanoic acids) from submerged macrophytes (Chara vulgaris), which inhibited the growth of toxic M. aeruginosa and the linoleic acid proved most potent. The combined activity of these three fatty acids exerted synergistic inhibitory effects on the growth of toxic $M$. aeruginosa. The previous reports indicated that four fatty acids (dodecanoic acid, tetradecanoic acid, hexadecanoic acid, linoleic acid) could control the growth of toxic M. aeurginosa, Chlorella pyrenoidosa Chick, and Scenedesmus obliques Kütz [21]. Linoleic acid was found to be the most inhibitory for $M$. aeruginosa. In addition, linoleic acid also was clearly able to inhibit the growth of Phormidium tenue [22], and Selenastrum capricornutum [23]. Fatty acids are widely distributed in aquatic and terrestrial environments, indicating the possibility that fatty acids in aquatic environments may affect cyanobacterial growth [4]. In our previous works, the $\mathrm{EC}_{50}$ of dihydroactinidiolide and $\beta$-ionone on $M$. aeruginosa were reported at $30.1 \pm 1.7$ and $25.3 \pm 2.1 \mathrm{mg} / \mathrm{L}$, respectively [24]. These compounds were also found in this study.

Three phthalate compounds (dimethyl phthalate, diethyl phthalate, 1,2-benzenedicarboxylic acid mono(2ethylhexyl)ester) were identified in the oils. Certain allelochemicals of phthalate had been studied for controlling microalgae growth. For example, diethyl phthalate could inhibit the growth of Dunaliella salina [25], and dibutyl phthalate was able to inhibit the growth of Gymnodinium breve [26]. Bie et al. [26] reported the mechanism of inhibitory action of dibutyl phthalate (DBP) on red tide algae $G$. breve. The effects of DBP on malonaldehyde (MDA), subcellular structure and superoxide dismutase (SOD) isoforms were investigated. The results showed that MDA accumulated in the algae cell under DBP exposure, and for the $3 \mathrm{mg} \cdot \mathrm{L}^{-1} \mathrm{DBP}$-treated algae culture a peak value of $0.34 \mu \mathrm{mol} \cdot\left(10^{9} \text { cells }\right)^{-1}$ occurred at $72 \mathrm{~h}$, which was about 2.3 times that of the control. TEM pictures showed the disruption of DBP on the subcellular structure of G. breve. A morphological phenomenon appeared whereby the algae cell was commonly found with small tubules or apical parts around the cell membrane, and almost all normal cell 
Table 1. Composition of essential oils from six submerged macrophytes.

\begin{tabular}{|c|c|c|c|c|c|c|c|}
\hline $\begin{array}{l}\text { Rent time } \\
\text { (min) }\end{array}$ & Compounds & P. cristatus & P. maackianus & P. lucens & V. spinulosa & C. demersum & H. verticillata \\
\hline 7.25 & 1-methyl-naphthalene & + & + & + & + & + & + \\
\hline 8.28 & dimethyl phthalate & + & - & + & + & + & + \\
\hline 8.31 & unknown & + & + & + & + & + & + \\
\hline 8.49 & $\beta$-ionone & + & + & - & - & + & + \\
\hline 8.64 & butylated hydroxytoluene & + & + & + & + & + & + \\
\hline 8.82 & dodecanoic acid & - & - & - & - & - & + \\
\hline 8.87 & dihydroactinidiolide & + & + & - & - & + & + \\
\hline 9.12 & diethyl phthalate & + & + & + & + & + & + \\
\hline 9.48 & ethyl citrate & + & + & + & + & + & + \\
\hline 9.57 & diisobutyl adipate & + & + & - & + & + & + \\
\hline 9.65 & heptadecane & + & + & + & - & + & + \\
\hline 9.99 & tetradecanoic acid & + & + & + & + & + & + \\
\hline 10.16 & tetradecanoic acid ethyl ester & + & - & - & - & + & - \\
\hline 10.20 & octadecane & + & + & + & - & + & + \\
\hline 10.33 & phenanthrene & - & - & - & + & + & + \\
\hline 10.45 & $\begin{array}{l}\text { 6,10,14-trimethyl-2- } \\
\text { pentadecanone }\end{array}$ & + & + & - & - & + & + \\
\hline 10.56 & pentadecanoic acid & + & - & - & + & + & + \\
\hline 10.67 & unknown & + & + & - & + & + & + \\
\hline 10.72 & nonadecane & + & + & - & - & - & + \\
\hline 11.03 & Z-11-hexadecenoic acid & - & - & + & + & - & + \\
\hline 11.09 & hexadecanoic acid & - & + & - & - & + & + \\
\hline 11.15 & unknown & + & + & + & + & + & + \\
\hline 11.20 & hexadecanoic acid ethyl ester & + & + & + & + & + & + \\
\hline 11.79 & phytol & + & + & + & + & + & + \\
\hline 11.94 & linoleic acid & + & + & + & + & + & + \\
\hline 12.01 & linoleic acid ethyl ester & + & + & - & - & + & + \\
\hline 12.16 & unknown & - & - & - & - & + & - \\
\hline 12.93 & (Z)-9-octadecenamide & + & + & - & - & - & + \\
\hline 13.88 & $\begin{array}{l}\text { 1,2-benzenedicarboxylic acid } \\
\text { mono(2-ethylhexyl) ester }\end{array}$ & + & + & + & + & + & + \\
\hline 14.10 & unknown & - & - & + & - & - & - \\
\hline 14.75 & 11-decyl-heneicosane & - & & - & - & - & - \\
\hline 18.32 & unknown & - & - & + & - & - & + \\
\hline 19.95 & vitamin $\mathrm{E}$ & - & - & - & - & + & - \\
\hline 21.96 & campesterol & - & - & - & - & + & - \\
\hline 22.59 & stigmasterol & - & + & + & - & - & + \\
\hline 23.86 & g-sitosterol & + & - & - & - & + & + \\
\hline
\end{tabular}


Table 2. Inhibitory effects of essential oils from the six submerged macrophytes on growth of M. aeruginosa.

\begin{tabular}{|l|c|c|c|c|c|c|}
\hline & P. cristatus & P. maackianus & P. lucens & V. spinulosa & C. demersum & H. verticillata \\
\hline Inhibition ratio & $35.1 \%$ & $36.2 \%$ & $32.9 \%$ & $41.7 \%$ & $30.2 \%$ & $36.6 \%$ \\
\hline
\end{tabular}

Table 3. $\mathrm{EC}_{50}(\mathrm{mg} / \mathrm{L})$ of four fatty acids on toxic M. aeurginosa, C. pyrenoidosa Chick, and S. obliques Kütz (the fifth day) [21].

\begin{tabular}{|l|c|c|c|}
\hline \multicolumn{1}{|c|}{ Compounds } & Microcystis aeruginosa & Chlorella pyrenoidosa & Scenedesmus obliquus \\
\hline Dodecanoic acid & 4.563 & 6.265 & 5.813 \\
\hline Tetradecanoic acid & 15.498 & 16.003 & 15.977 \\
\hline Hexadecanoic acid & 18.234 & 19.876 & 20.146 \\
\hline Linoleic acid & 0.047 & 0.089 & 0.059 \\
\hline
\end{tabular}

organelles were indistinguishable in the end. Chen [27] studied the release of phthalate esters and bioavailability during decomposition of tested submerged plants $(H$. verticilla) in the laboratory. He thought that the possible degradation pathway of DBP and di(2-ethylhexyl) phthalate (DEHP) were conferred by kinds of degradation products. That is to say, DBP and DEHP were first hydrolyzed into corresponding MBP, MEHP, and alcohols under the effect of esterase, and then to o-phthalic acid and benzoic acid gradually. At last, they were degraded into $\mathrm{CO}_{2}$ and $\mathrm{H}_{2} \mathrm{O}$.

These fatty acids, phthalate, dihydroactinidiolide, and $\beta$-ionone were found to be significantly active against cyanobacterial at low concentrations and are promising chemical agents for harmful algae control.

\section{Acknowledgements}

This work was kindly supported by the National Science-technology Support Plan Projects of China (2012BAJ21B06), National Natural Science Foundation of China (51108447; 51208485), China Postdoctoral Science Foundation Project (20100471208), China Postdoctoral Science special Foundation (201104499), the open foundation of State Key Laboratory of Freshwater Ecology and Biotechnology(2011FB03) and Science Foundation of Henan University of Urban Construction (2013JBS008).

\section{References}

1. YANG C. Y., LIU S. J., ZHOU S. W., WU H. F., YU J. B., XIA C.H. Allelochemical ethyl 2-methyl acetoacetate (EMA) induces oxidative damage and antioxidant responses in Phaeodactylum tricornutum. Pestic. Biochem. Phys. 100, (1), 93, 2011.

2. XIAN Q. M., CHEN H. D., LIU H. L., ZOU H. X., YIN D. Q. Isolation and Identification of Antialgal Compounds from the Leaves of Vallisneria spiralis L. by ActivityGuided Fractionation. Environ. Sci. Pollut. Res. 13, (4), 233, 2006.
3. GROSS E. M., MEYER H., SCHILLING G. Release and ecological impact of algicidal hydrolysable polyphenols in Myriophyllum spicatum. Phytochemistry 41, (1), 133, 1996.

4. NAKAI S., YAMADA S., HOSOMI M. Anti-cyanobacterial fatty acids released from Myriophyllum spicatum. Hydrobiologia 543, (1), 71, 2005.

5. ZHU J. Y., LIU B. Y., WANG J., GAO Y. N., WU Z. B. Study on the mechanism of allelopathic influence on cyanobacteria and chlorophytes by submerged macrophyte (Myriophyllum spicatum) and its secretion. Aquat. Toxicol. 98, (2), 196, 2010.

6. PAKDEL F. M., SIM L., BEARDALL J., DAVIS J. Allelopathic inhibition of microalgae by the freshwater stonewort, Chara australis, and a submerged angiosperm, Potamogeton crispus. Aquat. Bot. 110, 24, 2013.

7. GROSS E. M., ERHARD D., ENIKö I. Allelopathic activity of Ceratophyllum demersum L. and Najas marina ssp. Intermedia (Wolfgang) Casper. Hydrobiologia 506-509, (13), 583, 2003.

8. NAKAI S., INOUE Y., HOSOMI M., MURAKAMI A. Myriophyllum spicatum-released allelopathic polyphenols inhibiting growth of blue-green algae Microcystis aeruginosa. Water Res. 34, (11), 3026, 2000.

9. LEU E., KRIEGER-LISZKAY A., GOUSSIAS C., GROSS E. M. Polyphenolic allelochemicals from the aquatic angiosperm Myriophyllum spicatum inhibit photosystem II. Plant Physiol. 130, (4), 2011, 2002.

10. GAO, Y. N., LIU.B. Y., XU D., ZHOU Q. H., HU C. Y., GE F. J., ZHANG, L.P., WU, Z.B. Phenolic compounds exuded from two submerged freshwater macrophytes and their allelopathic effects on Microcystis aeruginosa. Pol. J. Environ. Stud. 20, (5), 1153, 2011.

11. RIPPKA R., DERUELLES J., WATERBURY J. B., HERDMAN M., STANIER R. Y. Generic assignments, strain histories and properties of pure cultures of cyanobacteria. J. Gen. Microbiol., 111, (1), 1, 1979.

12. XIAN Q. M., CHEN H. D., ZOU H. X., YIN D. Q. Allelopathic activity of volatile substances from submerged macrophytes on Microcystm aeruginosa. Acta Ecologica Sinica 26, (11), 3549, 2006 [In Chinese].

13. DE FIGUEIREDO D. R., AZEITEIRO U. M., ESTEVES S. M., GONCALVES F. J., PEREIRA M. J. Microcystinproducing blooms - a serious global public health issue. Ecotox. Environ. Safe. 59, (2), 151, 2004. 
14. ZHANG C., YI Y. L., HAO K., LIU G. L., WANG G. X. Algicidal activity of Salvia miltiorrhiza Bung on Microcystis aeruginosa - Towards identification of algicidal substance and determination of inhibition mechanism. Chemosphere 93, (6), 997, 2013.

15. HONG Y, HU H Y, SAKODA A, SAGEHASHI M. Isolation and characterization of antialgal allelochemicals from Arundo donax L. Allelopathy J. 25, (2), 357, 2010.

16. ZHANG S. L., ZHANG B., XING K. Z., ZHANG X., TIAN X., DAI W. Inhibitory effects of golden thread (Coptis chinensis) and berberine on Microcystis aeruginosa. Water Sci. Technol. 61, (3), 763, 2010.

17. WANG H. Q., CHENG S. P., ZHANG S. H., HE F., LIANG W., ZHANG L. P., HU C. Y., GE F. J.,WU Z. B. Chemical composition in aqueous extracts of Potamogeton malaianus and Potamogeton maackianus and their allelopathic effects on Microcystis aeruginosa. Pol. J. Environ. Stud. 19, (1), 213, 2010

18. WANG H. Q., LIANG F., QIAO N., DONG J. X., ZHANG L. Y., GUO Y. F. Chemical composition of volatile oil from two emergent plants and their algae inhibition activity. Pol. J. Environ. Stud. 23, (6), 2371, 2014.

19. MOHAMED Z. A., AL SHEHRI A. M. Differential Responses of Epiphytic and Planktonic Toxic Cyanobacteria to Allelopathic Substances of the Submerged Macrophyte Stratiotes aloides. Int. Rev. Hydrobiol. 95, (3), 224, 2010.

20. ZHANG T. T., HE M., WU A. P., NIE L. W. Allelopathic effect of surbmerbed macrophyte Chara vulgaris on toxic Microcystis aeruginosa. Allelopathy J. 23, (2), 391, 2009.
21. ZHANG T. T., ZHENG C. Y., HE M., WU A. P., NIE L. W. Inhibition on algae of fatty acids and the structure-effect relationship. China. Environ. Sci. 29, (3), 274, 2009 [In Chinese].

22. YAMADA N., MURAKAMI N., MORIMOTO T., SAKAKIBARA J. Auto-growth inhibitory substance from the freshwater cyanocbacterium Phormidium tenue. Chem. Pharm. Bull. 41, 1863, 1993.

23. HU C. Y., GE F. J., ZHANG S. H., LIU B. Y., WANG J., GAO Y. N., WU Z. B. Isolation of antialgal compounds from Potamogeton malaianus and algal inhibitory effects of common fatty acids. J. Lake Sci. 22, (4), 569, 2010 [In Chinese].

24. WANG H.Q., ZHU H.J., ZHANG L.Y., XUE W.J., YUAN B. Identification of Antialgal Compounds from the aquatic plant Elodea nuttallii. Allelopathy J. 34, (2), 207, 2014.

25. WANG J. J., QIAN X. J., AN M., DUAN S. S. Effect of combined exposure of diethylphthalate and nonylphenolon on growth of Dunaliella salina. Ecological Science 31, (4), 370, 2012 [In Chinese].

26. BIE C. C., LI F. M., WANG Y. F., WANG H. Y., ZHAO Y. H., ZHAO W., WANG Z. Y. Mechanism of the Inhibitory Action of Allelochemical Dibutyl Phthalate on Algae Gymnodinium breve. Environmental Science 33, (1), 228, 2012 [In Chinese].

27. CHEN B. Research on Release and Bioavailability of Phthalate Esters during the Decomposition of Hydrilla verticillata. Master's Degree Dissertation, Tianjin University 2009 [In Chinese]. 